\title{
Teachers' Perception About MOOCs and ICT During the COVID-19 Pandemic
}

\author{
Ricardo-Adán Salas-Rueda \\ Institute of Applied Sciences and Technology, National Autonomous University of Mexico, Mexico \\ ORCID: 0000-0002-4188-4610 \\ Ricardo Castañeda-Martínez \\ Institute of Applied Sciences and Technology, National Autonomous University of Mexico, Mexico \\ ORCID: 0000-0002-2225-7136 \\ Ana-Libia Eslava-Cervantes \\ Institute of Applied Sciences and Technology, National Autonomous University of Mexico, Mexico \\ ORCID: 0000-0002-7420-3412 \\ Clara Alvarado-Zamorano \\ Institute of Applied Sciences and Technology, National Autonomous University of Mexico, Mexico \\ ORCID: 0000-0001-9122-7590
}

Received: 20 Jun 2021

Accepted: 14 Oct 2021

\begin{abstract}
Technological advances such as Massive Open Online Courses (MOOCs) and Information and Communication Technologies (ICT) allow the construction of new spaces where students consult the information at any time, take the online exams and communicate with the participants of the educational process from anywhere. This quantitative research analyzes the perception of the teachers about the organization of the school activities in MOOCs and use of ICT considering machine learning and decision tree techniques (data science). The participants are 122 teachers (58 men and 64 women) from the National Autonomous University of Mexico who took the "Innovation in University Teaching 2020" Diploma. The academic degree of these educators is Bachelor ( $n=35,28.69 \%)$, Specialty $(n=4,3.28 \%)$, Master $(n=58,47.54 \%)$ and Doctorate $(n=25,20.49 \%)$. The results of machine learning (linear regressions) indicate that the organization of the school activities in MOOCs positively influences the motivation, participation and learning of the students. Data science identifies 3 predictive models about MOOCs and ICT through the decision tree technique. According to the teachers of the National Autonomous University of Mexico, the organization of the school activities in MOOCs and use of ICT play a fundamental role during the COVID-19 pandemic. The implications of this research promotes that educators use MOOCs and ICT to improve the educational conditions, create new remote school activities and build new virtual learning spaces. In conclusion, universities with the support of technological tools can improve the teaching-learning process and update the course during the COVID-19 pandemic. In particular, MOOCs represent a technological alternative to transform the school activities in the 21st century.
\end{abstract}

Keywords: MOOCs, teaching, data science, machine learning, ICT, COVID-19

\section{INTRODUCTION}

Today, MOOCs and ICT are transforming the behavior and functions of teachers and students in the educational field (Albelbisi et al., 2021; Jung \& Lee, 2018; Padilla-Rodriguez et al., 2020; Zhang et al., 2017). According to Poultsakis et al. (2021), the COVID-19 pandemic has caused that educators modify their 
educational practices through technological advances such as Digital Learning Objects (DLOs) and Digital Simulation Tools (DST). In the same way, teachers use MOOCs to organize creative school activities where students have an active role during the learning process (Almatrafi et al., 2018; Hsu et al., 2018; Otto et al., 2018).

During the 21st century, technological tools are causing that universities update the teaching-learning process in order to meet the demands of the students about the use of new educational methods and strategies (Doo et al., 2020; Papadakis et al., 2018; Pilli \& Admiraal, 2016; Zhou, 2017). For example, the incorporation of Learning Management Systems (LMS) such as Moodle in the educational field favors the interaction and communication at any time through mobile phones (Papadakis et al., 2017; Salas-Rueda et al., 2020). In addition, universities use virtual reality together with MOOCs to improve the teaching-learning conditions (Zhang et al., 2018). Similarly, the use of MOOCs and social networks such as Facebook and Twitter allow achieving the innovation in the educational field (Bozkurt et al., 2018).

The incorporation of MOOCs in the school activities is causing the creation of new educational spaces that favor the active role of students during the learning process (Adam, 2020; Brooker et al., 2018; Lee \& Chung, 2019). In fact, students actively participate in MOOCs by reviewing the videos (Chiu \& Hew, 2018), taking the online exams (Zhou, 2017), consulting the information (Brooker et al., 2018) and conducting the discussion forums (Chen et al., 2020; Xing, 2019). In particular, Coursera is increasing the number of students who use MOOCs (Kang, 2020; Thomas \& Nedeva, 2018; Zhou, 2017).

The benefits of MOOCs are related to the massive participation, realization of discussion forums and communication between the students and teachers (Li et al., 2020; Zhang et al., 2017). For example, Coursera, EdX, Iversity, XuetangX and ICourse163 allow that students consult the contents of the courses and actively participate from anywhere (Thomas \& Nedeva, 2018; Zhang et al., 2017). Likewise, MOOCs facilitate the organization and performance of collaborative activities at any time through the communication and discussion tools (Albelbisi \& Yusop, 2019; Li et al., 2020; Zhou, 2017). Also, these platforms allow the access to the information of the courses from anywhere (Fernandez-Díaz et al., 2020; Watson et al., 2018; Zhou, 2017).

Technological advances are changing the planning and organization of the courses under the distance and face-to-face modalities (Arnavut et al., 2020; Kim et al., 2021; Zhu et al., 2021). In particular, the incorporation of MOOCs in the school activities allows the creation of new virtual spaces for learning and teaching (Albelbisi et al., 2021; Kim et al., 2021; Lorente-Ruiz et al., 2021). During the COVID-19 pandemic, educators looked for and used new educational strategies and ICT to plan creative activities, update the courses and facilitate the teaching-learning process at any time (Del-Castillo-Olivares \& Del-Castillo-Olivares, 2021).

This quantitative research analyzes the perception of the teachers about the organization of the school activities in MOOCs and use of ICT considering machine learning and decision tree techniques (data science). Therefore, the research questions are:

- What is the impact about the organization of the school activities in MOOCs?

- How the organization of the school activities in MOOCs influences the use of ICT for the motivation, participation and learning of the students?

- What is the impact about the use of ICT in the motivation, participation and learning of the students?

- What are the predictive models about the organization of the school activities in MOOCs and use of ICT in the educational field?

\section{MOOCS AND ICT IN THE EDUCATIONAL FIELD}

Technological advances such as MOOCs and ICT are changing the planning, organization and implementation of the school activities in the 21st century (Almeida \& Hilleshein-de-Souza, 2020; Li, 2017; Oliveira, 2019; Vazde-Oliveira, 2017). Various countries such as the United States, China and Spain are using MOOCs to update 
courses and facilitate the personalization of the learning process (Wahid et al., 2020). For example, the use of MOOCs in the English course facilitated the students' autonomy and increased the motivation during the teaching-learning process (Kim et al., 2021). Also, mobile devices such as smartphone and tablet are changing the way to consult the information in these technological tools (Shen, 2018).

According to Arnavut et al. (2020), the Connectivism Theory of Siemens about the technological development and change of the human lives caused the emergence of MOOCs. In fact, the appearance of these technological tools in the educational field was in 2008 (Lorente-Ruiz et al., 2021). At Stanford University, a MOOC different from Siemens called XMOOC was designed in 2011 considering the traditional teaching style (Khalid et al., 2020). Currently, MOOCs allow the consultation of videos, realization of discussion forums and resolution of online exams from anywhere (Joo et al., 2018; Oudeweetering \& Agirdag, 2018; Tsai et al., 2018).

Initially, MOOCs were used to meet the educational demands of adults (Arnavut et al., 2020; Zhu et al., 2021). Over time, the openness and flexibility of these technological tools led that universities design new courses to facilitate the teaching-learning process from any country (Zhu et al., 2021).

The incorporation of MOOCs in the school activities has led to the optimization of flexibility, time availability, tuition costs, student coverage and previous requirements (Albelbisi et al., 2021; Medina-Labrador et al., 2020). Since 2013, Spanish universities invested in these technological tools to improve the educational quality through the organization and implementation of courses about Mathematics, Physics and Chemistry (Lorente-Ruiz et al., 2021).

Furthermore, Albelbisi et al. (2021) mention that the interest of the students about the use of MOOCs is increasing due to the flexibility of time and space during the teaching-learning process. In Turkey, the teachers of primary, secondary and university used Blended Learning and MOOCs to facilitate the active role of students from anywhere (Arnavut et al., 2020).

\section{Use of MOOCs in the Educational Field}

Today, teachers use MOOCs to create new learning spaces and carry out creative school activities (Cisel, 2019; Li et al., 2020; Wise \& Cui, 2018). For example, the use of MOOCs improved the teaching-learning conditions in the courses of Bioelectricity (Zhou, 2017), Education (Brooker et al., 2018), Introduction to Programming (Luik \& Lepp, 2021), Poetry (Chiu \& Hew, 2018), Pedagogy (Bozkurt et al., 2018), Informatics (Ji, 2016), Modern Educational Technology (Li, 2017), Administration (Kang, 2020), News Transmission (Shen, 2018), Statistics (You, 2019), and Psychology (Martin et al., 2018).

In the Introduction to Programming course, the students developed their computer skills, increased their motivation and participated actively from anywhere through a MOOC (Luik \& Lepp, 2021). In the same way, Duke University transformed the teaching-learning process about bioelectricity through the incorporation of technology in the school activities (Zhou, 2017). In particular, the use of a MOOC facilitated the assimilation of knowledge about bioelectricity by consulting the content and taking the exams at any time (Zhou, 2017).

Educational institutions are using MOOCs to offer different courses and facilitate the learning process from anywhere (Brooker et al., 2018; Shukor \& Abdullah, 2019). For example, the University of Melbourne in partnership with Coursera designed the course of "Assessment and Teaching Skills in the Twenty First Century MOOC" (ATS21C) in order to facilitate the assimilation of knowledge about pedagogy and develop the skills about the assessment in the educational field (Brooker et al., 2018). In the same way, the MOOC called "Job Success" on Coursera facilitated the learning process about administration by consulting the videos and taking the online exams (Kang, 2020).

Technological advances such as MOOCs are changing the way of organizing and carrying out the school activities (Carmo-Silva et al., 2020; Chiu \& Hew, 2018; Khalid et al., 2020; Paton et al., 2018). For example, Coursera offered the Poetry course where students consulted videos in the English, Spanish and German languages at any time (Chiu \& Hew, 2018). Even, the students of the Poetry course participated actively in 
this MOOC through the delivery of writing assignments and realization of discussion forums (Chiu \& Hew, 2018).

According to Wahid et al. (2020), the use of MOOCs has improved the educational process in the areas of Computer science, Social sciences, Engineering, Mathematics, Decision sciences, Medicine, Psychology, Education and Chemistry (Wahid et al., 2020). In the Psychological Perspectives course, the students played a leading role during the learning process about sports psychology by consulting the videos and taking the exams in MOOC (Martin et al., 2018). The results about the use of this technological tool are the improvement of the academic performance, construction of new educational virtual spaces and increased of the motivation during the realization of school activities (Martin et al., 2018). Also, Coursera and Twitter facilitated the analysis, discussion, and interpretation about digital education topics and developed the students' skills (Bozkurt et al., 2018).

In Shandong, the use of the MOOC in the school activities facilitated the learning process during the Modern Educational Technology course through the consultation of audio materials, videos, and animations (Li, 2017). In fact, these students actively participated during the learning process, increased their motivation, and improved their academic performance ( $L i, 2017)$.

In the News Transmission course, the use of a MOOC facilitated the assimilation of knowledge and developed the skills of the students through the consultation of audio materials and videos (Shen, 2018). In fact, mobile devices such as smartphones and tablets allowed the consultation of information from anywhere and realization of the collaborative work during this course (Shen, 2018). In the same way, the students of the Statistics course used a MOOC to develop their mathematical skills and realize the discussion forums and online exams (You, 2019).

The incorporation of MOOCs in the field of computing facilitated the development of digital skills, realization of the school activities from any place and communication between teachers and students during the learning process (Jafari et al., 2018; Ji, 2016; Paton et al., 2018). In the Fundamentals of Computers course, the consultation of the audiovisual contents in MOOCs increased the enthusiasm of the students, facilitated the learning process about computing, allowed the autonomy of the participants and improved the academic performance (Ji, 2016).

Also, Santoso et al. (2019) mention that the design of MOOCs must allow sending the messages to the instructor, conducting the discussion forums, paying for certificates, submitting the assignments and taking the exams online. Finally, teachers have the opportunity to improve the teaching-learning conditions through technology (Broeck et al, 2020; Gregori et al., 2018; Medina-Labrador et al., 2020; Shen, 2018). In particular, the use of MOOCs in the educational field facilitates the active participation of students (Broeck et al, 2020; Chen et al., 2020), increases the motivation during the learning process (Hsu et al., 2018; Lee \& Chung, 2019) and improves the academic performance (Xing, 2019; You, 2019).

\section{METHOD}

The general aim of this quantitative research is to analyze the perception of the teachers about the organization of the school activities in MOOCs and use of ICT in the educational field considering machine learning and decision tree techniques (data science). The particular aims are (1) analyze the impact about the organization of the school activities in MOOCs (2) analyze the impact of ICT in the motivation, participation and learning of the students (3) analyze the impact of MOOCs in the motivation, participation and learning of the students through the machine learning technique and (4) establish 3 predictive models about the organization of the school activities in MOOCs and use of ICT through the decision tree technique.

\section{Participants}

The participants are 122 teachers (58 men and 64 women) from the National Autonomous University of Mexico who took the "Innovation in University Teaching 2020" Diploma. The academic degree of these 


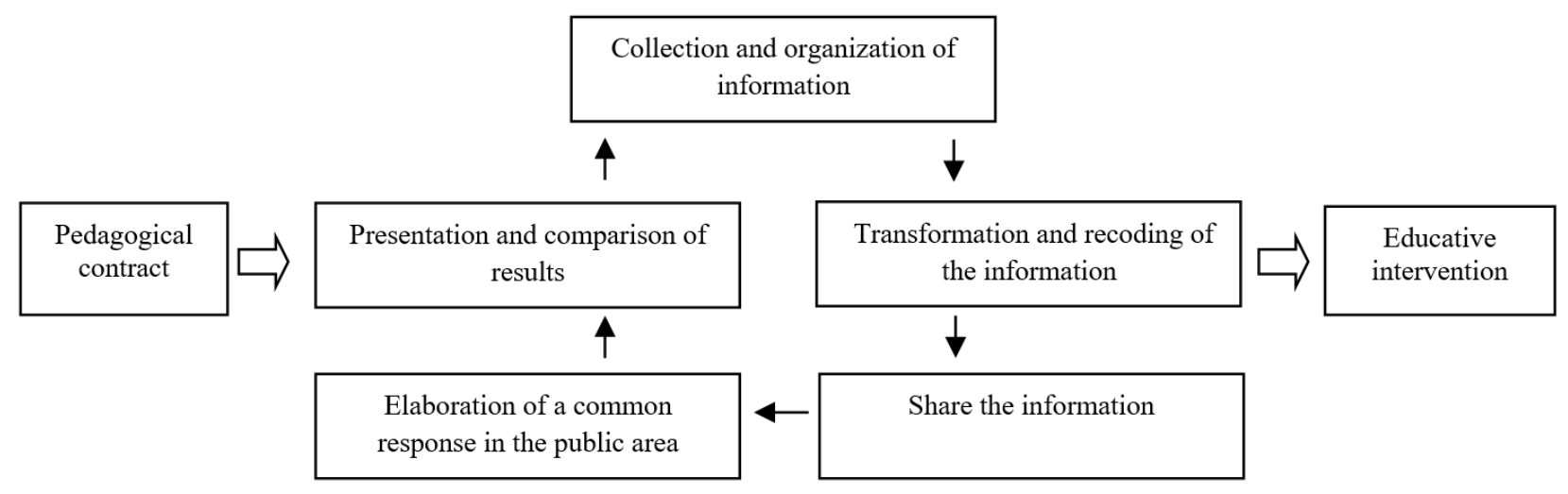

Analysis

Classroom of the Future model

Implementation

Figure 1. "Innovation in University Teaching" diploma
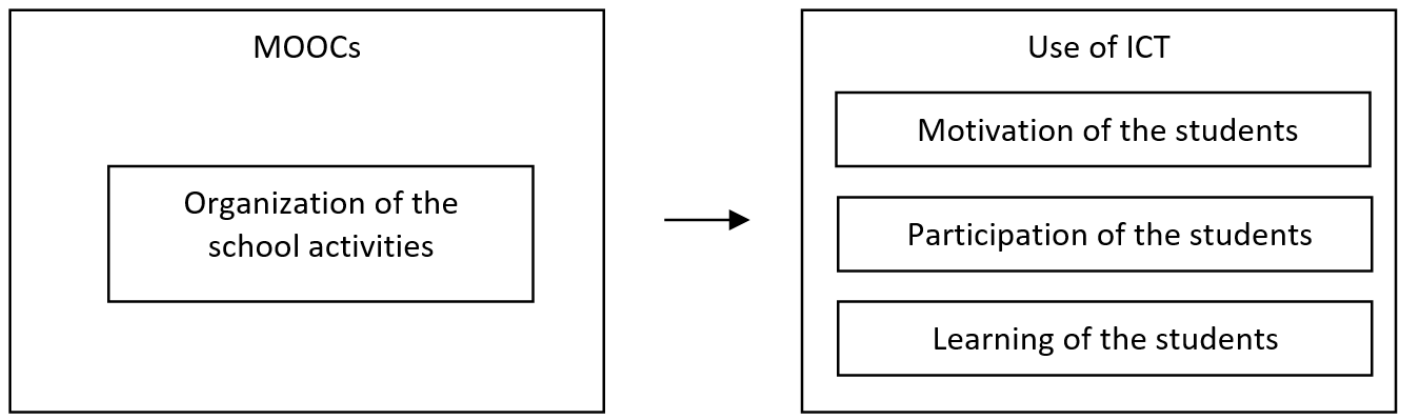

Figure 2. Model used to analyze the perception of the teachers

educators is Bachelor ( $n=35,28.69 \%)$, Specialty $(n=4,3.28 \%)$, Master $(n=58,47.54 \%)$ and Doctorate $(n=$ $25,20.49 \%)$.

\section{Procedure}

In May 2020, the National Autonomous University of Mexico offered the "Innovation in University Teaching" Diploma to facilitate the teaching-learning process during the COVID-19 pandemic through the use of the pedagogic and technological model called "Classroom of the Future" (See Figure 1).

Figure 2 shows the model used to analyze the perception of the teachers about the organization of the school activities in MOOCs and use of ICT considering data science.

The COVID-19 pandemic is causing that teachers seek new ways to facilitate the learning process (Atencio et al., 2021; Grande-de-Prado et al., 2021; Llorens-Largo et al., 2021). In particular, MOOCs allow the access to the information at any time and increase the motivation of the students during the learning process (Chen et al., 2020; Joo et al., 2018; Oudeweetering \& Agirdag, 2018). Therefore, the hypothesis about MOOCs and the motivation is:

- Hypothesis $1(\mathrm{H} 1)$ : The organization of the school activities in MOOCs positively influences the motivation of the students

Various authors (e.g., Jafari et al., 2018; Ji, 2016; Paton et al., 2018) mention that MOOCs allow the creation of new educational spaces in order to facilitate the active role of the students during the learning process. Therefore, the hypothesis about MOOCs and the participation of the students is:

- Hypothesis $2(\mathrm{H} 2)$ : The organization of the school activities in MOOCs positively influences the participation of the students 
Table 1. Questionnaire about MOOCs and use of ICT

\begin{tabular}{|c|c|c|c|c|c|c|}
\hline No. & Variable & Dimension & Question & Answer & $\mathrm{n}$ & $\%$ \\
\hline \multirow[t]{7}{*}{1} & Profile of the & Sex & 1. Indicate your sex & & & \\
\hline & teachers & & & Man & 58 & $47.54 \%$ \\
\hline & & & & Woman & 64 & $52.46 \%$ \\
\hline & & $\begin{array}{l}\text { Maximum } \\
\text { degree of study }\end{array}$ & $\begin{array}{l}\text { 2. Indicate your maximum } \\
\text { degree of study }\end{array}$ & Bachelor's degree & 35 & $28.69 \%$ \\
\hline & & & & Specialty's degree & 4 & $3.28 \%$ \\
\hline & & & & Master's degree & 58 & $47.54 \%$ \\
\hline & & & & Doctorate's degree & 25 & $20.49 \%$ \\
\hline \multirow[t]{16}{*}{2} & $\begin{array}{l}\text { Technology in } \\
\text { the educational }\end{array}$ & MOOCs & $\begin{array}{l}\text { 3. MOOCs facilitate the } \\
\text { organization of new school }\end{array}$ & Very much (1) & 35 & $28.69 \%$ \\
\hline & field & & activities & Much (2) & 47 & $38.52 \%$ \\
\hline & & & & Little (3) & 36 & $29.51 \%$ \\
\hline & & & & Very little (4) & 4 & $3.28 \%$ \\
\hline & & $\begin{array}{l}\text { Motivation of } \\
\text { the students }\end{array}$ & $\begin{array}{l}\text { 4. The use of ICT in the } \\
\text { educational field increases the }\end{array}$ & Very much (1) & 56 & $45.90 \%$ \\
\hline & & & motivation of the students & Much (2) & 51 & $41.80 \%$ \\
\hline & & & & Little (3) & 15 & $12.30 \%$ \\
\hline & & & & Very little (4) & 0 & $0.00 \%$ \\
\hline & & $\begin{array}{l}\text { Participation of } \\
\text { the students }\end{array}$ & $\begin{array}{l}\text { 5. The use of ICT in the } \\
\text { educational field increases the }\end{array}$ & Very much (1) & 59 & $48.36 \%$ \\
\hline & & & participation of the students & Much (2) & 47 & $38.52 \%$ \\
\hline & & & & Little (3) & 15 & $12.30 \%$ \\
\hline & & & & Very little (4) & 1 & $0.82 \%$ \\
\hline & & $\begin{array}{l}\text { Learning of the } \\
\text { students }\end{array}$ & $\begin{array}{l}\text { 6. The use of ICT in the } \\
\text { educational field facilitates the }\end{array}$ & Very much (1) & 58 & $47.54 \%$ \\
\hline & & & learning of the students & Much (2) & 39 & $31.97 \%$ \\
\hline & & & & Little (3) & 23 & $18.85 \%$ \\
\hline & & & & Very little (4) & 2 & $1.64 \%$ \\
\hline
\end{tabular}

The use of MOOCs in the educational field facilitates the understanding of school subjects from anywhere (Li, 2017). Therefore, the hypothesis about MOOCs and the learning of the students is:

- Hypothesis $3(\mathrm{H} 3)$ : The organization of the school activities in MOOCs positively influences the learning of the students

Data science identifies the following predictive models about the organization of the school activities in MOOCs and use of ICT through the decision tree technique:

- Predictive Model 1 (PM1) about the organization of the school activities in MOOCs and use of ICT for the motivation of the students

- Predictive Model 2 (PM2) about the organization of the school activities in MOOCs and use of ICT for the participation of the students

- Predictive Model 3 (PM3) about the organization of the school activities in MOOCs and use of ICT for the learning of the students

\section{Data Collection}

Data collection was carried out during the realization of "Innovation in University Teaching" Diploma at National Autonomous University of Mexico. Table 1 shows the questionnaire used to collect the data about MOOCs and use of ICT. 
Table 2. Validation of the questionnaire about MOOCs and use of ICT

\begin{tabular}{llcccc}
\hline Variable & Dimension & Load factor & $\begin{array}{c}\text { Cronbach's } \\
\text { Alpha }\end{array}$ & $\begin{array}{c}\text { Average Variance } \\
\text { Extracted }\end{array}$ & $\begin{array}{c}\text { Composite } \\
\text { Reliability }\end{array}$ \\
\hline Technology in & MOOCs & 0.547 & 0.743 & 0.584 & 0.845 \\
the educational & Motivation of students & 0.811 & & & \\
field & Participation of students & 0.856 & & & \\
& Learning of students & 0.804 & & & \\
\hline
\end{tabular}

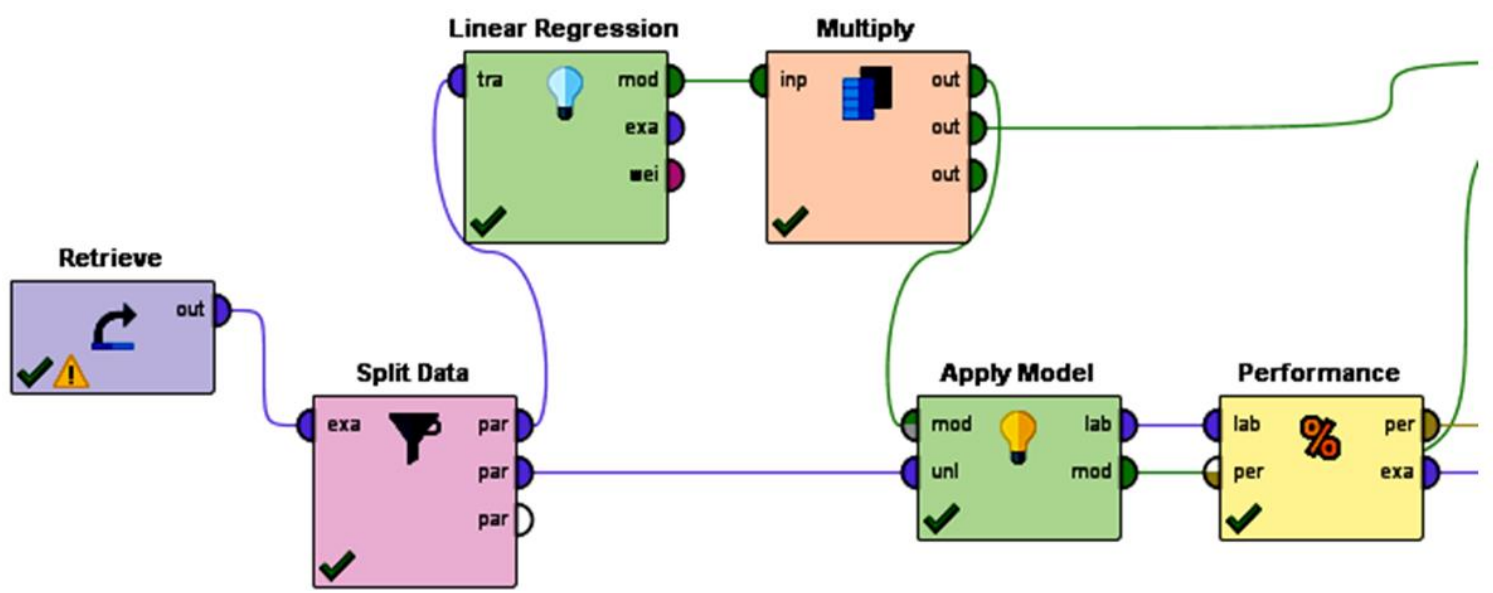

Figure 3. Use of the Rapidminer tool for the machine learning technique

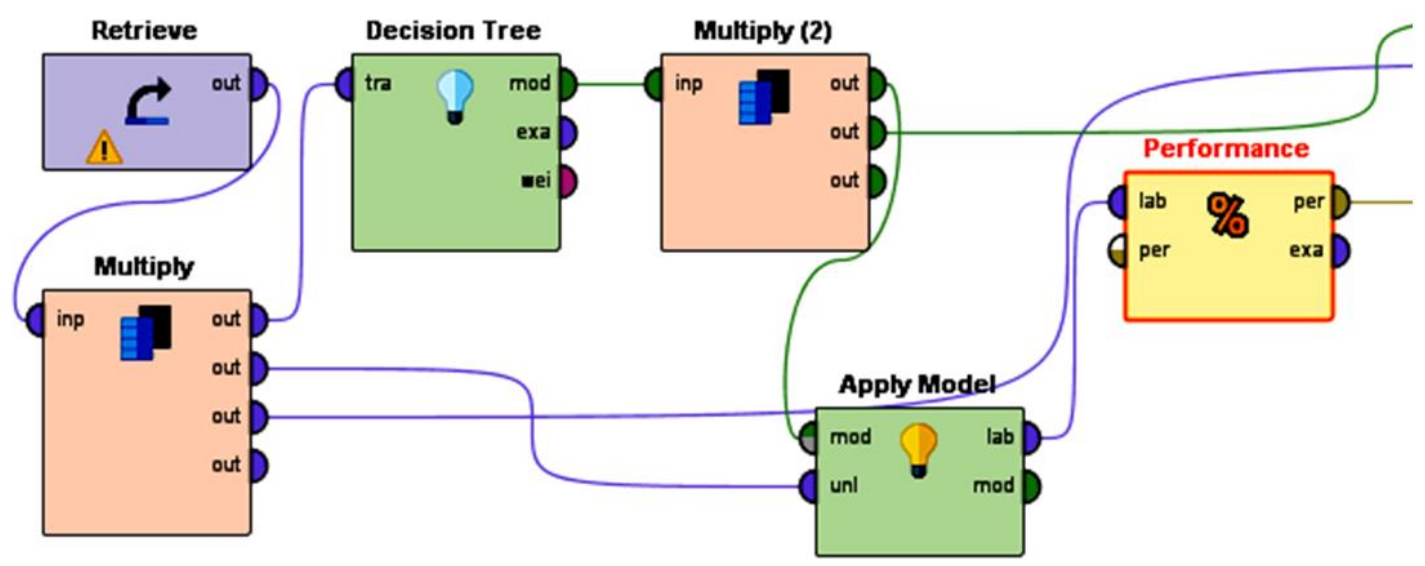

Figure 4. Use of the Rapidminer tool for the decision tree technique

The values of the Load factor $(>0.500)$, Cronbach's Alpha $(>0.600)$ and Composite Reliability $(>0.700)$ are necessary to validate the questionnaire. Table 2 shows that the values of the Load Factor $(>0.546)$, Cronbach's Alpha (>0.740) and Composite Reliability (>0.840) allow validating the questionnaire. Also, the SPSS software allowed the Exploratory Factor Analysis (EFA) of the "Technology in the educational" variable.

\section{Data Analysis}

This research uses the Rapidminer tool to calculate the linear regressions about MOOCs and use of ICT through the machine learning technique and build the predictive models considering the decision tree technique (data science).

Machine learning allows evaluating the research hypotheses through the training section $(50 \%, 60 \%$ and $70 \%$ of the sample). The evaluation section ( $50 \%, 40 \%$ and $30 \%$ of the sample) allows knowing the accuracy of these linear regressions (See Figure 3).

Data science allows the construction of the predictive models about MOOCs and use of ICT through the decision tree technique. The information about the use of ICT, MOOCs and teacher's profile is used to build 3 predictive models about the motivation, participation and learning of the students (See Figure 4). 
Table 3. Results of machine learning

\begin{tabular}{lcccc}
\hline Hypothesis & Training & Linear regression & Conclusion & Error squared \\
\hline H1: Organization of school activities & $50 \%$ & $y=0.172 x+1.235$ & Accepted: 0.172 & 0.473 \\
in MOOCs $\rightarrow$ motivation of the & $60 \%$ & $y=0.180 x+1.231$ & Accepted: 0.180 & 0.500 \\
students & $70 \%$ & $y=0.192 x+1.234$ & Accepted: 0.192 & 0.442 \\
\hline H2: Organization of school activities & $50 \%$ & $y=0.264 x+1.039$ & Accepted: 0.264 & 0.449 \\
in MOOCs $\rightarrow$ participation of the & $60 \%$ & $y=0.292 x+0.977$ & Accepted: 0.292 & 0.491 \\
students & $70 \%$ & $y=0.298 x+0.997$ & Accepted: 0.298 & 0.484 \\
\hline H3: Organization of school activities & $50 \%$ & $y=0.230 x+1.275$ & Accepted: 0.230 & 0.526 \\
in MOOCs $\rightarrow$ learning of the students & $60 \%$ & $y=0.248 x+1.207$ & Accepted: 0.248 & 0.524 \\
& $70 \%$ & $y=0.239 x+1.240$ & Accepted: 0.239 & 0.486 \\
\hline
\end{tabular}

Table 4. Pearson's correlations

\begin{tabular}{lcccc}
\hline & $\begin{array}{c}\text { Motivation of the } \\
\text { students }\end{array}$ & $\begin{array}{c}\text { Participation of the } \\
\text { students }\end{array}$ & $\begin{array}{c}\text { Learning of the } \\
\text { students }\end{array}$ & MOOCs \\
\hline Motivation of the students & 1 & - & - & - \\
Participation of the students & 0.612 & 1 & - & - \\
Learning of the students & 0.522 & 0.576 & 1 & - \\
MOOCs & 0.256 & 0.339 & 0.290 & 1 \\
\hline
\end{tabular}

\section{RESULTS}

MOOCs facilitate very much $(n=35,28.69 \%)$, much $(n=47,38.52 \%)$, little $(n=36,29.51 \%)$, and very little ( $n$ $=4,3.28 \%$ ) the organization of new school activities (See Table 1). Also, the results of machine learning indicate that the organization of the school activities in MOOCs positively influences the motivation, participation and learning of the students (See Table 3).

Table 4 shows the Pearson's correlations about MOOCs and the use of ICT for the motivation, participation and learning of the students. The most significant value is located in the Participation of the students and MOOCs (0.339). On the other hand, the least significant value is located in the Motivation of the students and MOOCs (0.256).

\section{Motivation of the Students}

The use of ICT in the educational field increases very much $(n=56,45.90 \%)$, much $(n=51,41.80 \%)$, and little ( $n=15,12.30 \%$ ) the motivation of the students (See Table 1 ). The results of machine learning with $50 \%$ (0.172), 60\% (0.180) and 70\% (0.192) of training indicate that $\mathrm{H} 1$ is accepted (See Table 3). Therefore, the organization of the school activities in MOOCs positively influences the motivation of the students. On the other hand, the Pearson's coefficient about MOOCs and the motivation of students is 0.256 .

Table 5 shows 10 conditions of the PM1 about the organization of the school activities in MOOCs and use of ICT for the motivation of the students. For example, if the teacher considers that MOOCs facilitate very much the organization of new school activities and has the doctorate's degree then the use of ICT in the educational field increases very much the motivation of the students. Similarly, if the teacher considers that MOOCs facilitate very much the organization of new school activities and has the bachelor's degree then the use of ICT in the educational field increases very much the motivation of the students. 
Table 5. PM1 about MOOCs and the motivation of the students

\begin{tabular}{|c|c|c|c|c|}
\hline No. & $\begin{array}{c}\text { MOOCs } \rightarrow \text { organization of new school } \\
\text { activities }\end{array}$ & Sex & $\begin{array}{l}\text { Maximum degree of } \\
\text { study }\end{array}$ & $\begin{array}{c}\text { ICT } \rightarrow \text { motivation of the } \\
\text { students }\end{array}$ \\
\hline 1 & Very much & - & Doctorate's degree & Very much \\
\hline 2 & Very much & - & Master's degree & Very much \\
\hline 3 & Very much & - & Specialty's degree & Much \\
\hline 4 & Very much & - & Bachelor's degree & Very much \\
\hline 5 & Much & - & - & Much \\
\hline 6 & Little & - & Doctorate's degree & Little \\
\hline 7 & Little & - & Master's degree & Much \\
\hline 8 & Little & - & Specialty's degree & Little \\
\hline 9 & Little & - & Bachelor's degree & Much \\
\hline 10 & Very little & - & - & Little \\
\hline
\end{tabular}

Table 6. PM2 about MOOCs and the participation of the students

\begin{tabular}{lcccc}
\hline No. & $\begin{array}{c}\text { MOOCs } \rightarrow \text { organization of new school } \\
\text { activities }\end{array}$ & Sex & $\begin{array}{c}\text { Maximum degree of } \\
\text { study }\end{array}$ & $\begin{array}{c}\text { ICT } \rightarrow \text { participation of } \\
\text { the students }\end{array}$ \\
\hline 1 & Very much & - & Doctorate's degree & Very much \\
2 & Very much & - & Master's degree & Very much \\
3 & Very much & - & Specialty's degree & Much \\
4 & Very much & - & Bachelor's degree & Very much \\
5 & Much & - & Doctorate's degree & Very much \\
6 & Much & - & Master's degree & Very much \\
7 & Much & - & Specialty's degree & Much \\
8 & Much & - & Bachelor's degree & Much \\
9 & Little & - & - & Little \\
10 & Very little & Man & - & Much \\
11 & Very little & Woman & - & Little \\
\hline
\end{tabular}

\section{Participation of the Students}

The use of ICT in the educational field increases very much ( $n=59,48.36 \%)$, much $(n=47,38.52 \%)$, little ( $n$ $=15,12.30 \%)$, and very little $(n=1,0.82 \%)$ the participation of the students (See Table 1$)$. The results of machine learning with $50 \%(0.264), 60 \%(0.292)$ and $70 \%(0.298)$ of training indicate that $\mathrm{H} 2$ is accepted (See Table 3). Therefore, the organization of the school activities in MOOCs positively influences the participation of the students. On the other hand, the Pearson's coefficient about MOOCs and the participation of the students is 0.339 .

Table 6 shows 11 conditions of the PM2 about the organization of the school activities in MOOCs and use of ICT for the participation of the students. For example, if the teacher considers that MOOCs facilitate very much the organization of new school activities and has the Doctorate's degree then the use of ICT in the educational field increases very much the participation of the students. On the other hand, if the teacher considers that MOOCs facilitate much the organization of new school activities and has the doctorate's degree then the use of ICT in the educational field increases very much the participation of the students.

\section{Learning of Students}

The use of ICT in the educational field facilitates very much ( $n=58,47.54 \%)$, much $(n=39,31.97 \%)$, little ( $n$ $=23,18.85 \%)$, and very little $(n=2,1.64 \%)$ the learning of the students (See Table 1$)$. The results of machine learning with $50 \%(0.230), 60 \%(0.248)$ and $70 \%(0.239)$ of training indicate that $\mathrm{H} 3$ is accepted (See Table 3 ). Therefore, the organization of the school activities in MOOCs positively influences the learning of the students. On the other hand, the Pearson's coefficient about MOOCs and the learning of students is 0.290.

Table 7 shows 8 conditions of the PM3 about the organization of the school activities in MOOCs and use of ICT for the learning of the students. For example, if the teacher considers that MOOCs facilitate much the organization of new school activities and has the doctorate's degree then the use of ICT in the educational 
Table 7. PM3 about MOOCs and the learning of the students

\begin{tabular}{lcccc}
\hline No. & $\begin{array}{c}\text { MOOCs } \rightarrow \text { organization of new } \\
\text { school activities }\end{array}$ & Sex & $\begin{array}{c}\text { Maximum degree of } \\
\text { study }\end{array}$ & ICT $\rightarrow$ learning of the students \\
\hline 1 & Very much & - & - & Very much \\
2 & Much & - & Doctorate's degree & Very much \\
3 & Much & - & Master's degree & Much \\
4 & Much & - & Specialty's degree & Very much \\
5 & Much & - & Bachelor's degree & Much \\
6 & Little & - & - & Little \\
7 & Very little & Man & - & Much \\
8 & Very little & Woman & - & Little \\
\hline
\end{tabular}

field facilitates very much the learning of the students. In the same way, if the teacher considers that MOOCs facilitate much the organization of new school activities and has the specialty's degree then the use of ICT in the educational field facilitates very much the learning of the students.

\section{DISCUSSION}

Educational institutions use MOOCs to improve the teaching-learning conditions (Hsu et al., 2018; Lee \& Chung, 2019; Martin et al., 2018). Similar to Kim et al. (2021), this technological tool allowed the construction of new virtual spaces that facilitate the educational process about the English Language. As a result of the analysis performed, $38.52 \%$ of the teachers $(n=47)$ thinks that MOOCs facilitate much the organization of new school activities. Also, MOOCs facilitate very much $(n=35,28.69 \%)$ the organization of new school activities. Therefore, the majority of the educators (67.21\%) have a favorable opinion about this technological tool.

\section{Motivation of Students}

According to Mailizar et al. (2021), the incorporation of technological tools allows the construction of new virtual spaces that favor the learning, motivation and satisfaction of the students. In particular, $45.90 \%$ of the teachers $(n=56)$ thinks that the use of ICT in the educational field increases very much the motivation of the students. Also, analysis showed that the use of ICT in the educational field increases much $(n=51,41.80 \%)$ the motivation of the students. Therefore, the majority of the educators (87.70\%) have a favorable opinion.

This research shares the ideas of various authors (e.g., Bozkurt et al., 2018; Brooker et al., 2018; Gamage et al., 2020) about the use of MOOCs to increase the motivation of the students. In fact, teachers use these technological tools and pedagogical models such as Blended Learning to innovate the school activities (Arnavut et al., 2020). The results of machine learning on $\mathrm{H} 1$ are higher than 0.170 , therefore, the organization of the school activities in MOOCs positively influences the motivation of the students. Also, the Pearson's coefficient about MOOCs and the motivation of the students is higher than 0.250 .

Data science identifies 10 conditions of the PM1. In this predictive model, the Maximum degree of study determines how the organization of new school activities in MOOCs influences the use of ICT for the motivation of the students. The decision tree technique identifies 3 conditions where the use of ICT in the educational field increases very much the motivation of the students. For example, if the teacher considers that MOOCs facilitate very much the organization of new school activities and has the Doctorate's degree then the use of ICT in the educational field increases very much the motivation of the students.

On the other hand, the PM1 has 4 predictive conditions related to the Much category about the motivation of the students. For example, if the teacher considers that MOOCs facilitate very much the organization of new school activities and has the Specialty's degree then the use of ICT in the educational field increases much the motivation of the students. Also, this predictive model has 3 predictive conditions related to the Little category about the motivation of the students. For example, if the teacher considers that MOOCs facilitate little the organization of new school activities and has the doctorate's degree then the use of ICT in the educational field increases little the motivation of the students. 


\section{Participation of Students}

As Njiku et al. (2021) indicated, teachers use technology tools to organize and conduct creative studentcentered activities. For example, the use of a MOOC in the Statistics course facilitated the active role of the participants inside and outside the classroom (You, 2019). In particular, $48.36 \%$ of the teachers $(n=59)$ thinks that the use of ICT in the educational field increases very much the participation of the students. Likewise, quantitative data reveals that the use of ICT in the educational field increases much $(n=47,38.52 \%)$ the participation of the students. Therefore, the majority of the educators $(86.88 \%)$ have a favorable opinion.

The incorporation of MOOCs in the school activities favors the participation of the students at any time (Cisel, 2019; Crues et al., 2018; Li et al., 2020). In particular, the students consulted the contents about bioelectricity and took the exams from anywhere through a MOOC (Zhou, 2017). The results of machine learning on $\mathrm{H} 2$ are higher than 0.260 , therefore, the organization of the school activities in MOOCs positively influence the participation of the students. Also, the Pearson's coefficient about MOOCs and the participation of students is higher than 0.330 .

Data science identifies 11 conditions of the PM2. In this predictive model, the Maximum degree of study and Sex of the educators determine how the organization of new school activities in MOOCs influences the use of ICT for the participation of the students. The decision tree technique identifies 5 conditions where the use of ICT in the educational field increases very much the participation of the students. For example, if the teacher considers that MOOCs facilitate much the organization of new school activities and has the doctorate's degree then the use of ICT in the educational field increases very much the participation of the students.

On the other hand, the PM2 has 4 predictive conditions related to the Much category about the participation of the students. For example, if the teacher considers that MOOCs facilitate much the organization of new school activities and has the bachelor's degree then the use of ICT in the educational field increases much the participation of the students. Also, this predictive model has 2 predictive conditions related to the Little category about the participation of the students. For example, if the teacher considers that MOOCs facilitate little the organization of new school activities and has the doctorate's degree then the use of ICT in the educational field increases little the participation of the students.

\section{Learning of the Students}

This study shares the ideas of various authors (e.g., Kara, 2021; Persson \& Nouri, 2018; Zhang \& Zuo, 2019) about the use of technological tools to improve the teaching-learning conditions. As mentioned by Luik and Lepp (2021), the use of a MOOC facilitated the development of digital skills and increased the motivation of the students in the Introduction to Programming course. As a result of the analysis performed, $47.54 \%$ of the teachers $(n=58)$ thinks that the use of ICT in the educational field facilitates very much the learning of the students. Also, the use of ICT in the educational field facilitates much ( $n=39,31.97 \%$ ) the learning of the students. Therefore, the majority of the educators (79.51\%) have a favorable opinion.

Various authors (e.g., Liu et al., 2018; Persson \& Nouri, 2018; Shen, 2018; Zhang \& Zuo, 2019) highlight the role of ICT and MOOCs to carry out the school activities at any time and facilitate the learning process. For example, the consultation of the videos and realization of the online exams in a MOOC facilitated the assimilation of the knowledge about the administration (Kang, 2020). The results of machine learning on $\mathrm{H} 3$ are higher than 0.220 , therefore, the organization of the school activities in MOOCs positively influence the learning of students. Also, the Pearson's coefficient about MOOCs and the learning of the students is higher than 0.289 .

Data science identifies 8 conditions of the PM3. In this predictive model, the Maximum degree of study and Sex of the educators determine how the organization of new school activities in MOOCs influences the use of ICT for the learning of the students. The decision tree technique identifies 3 conditions where the use of ICT in the educational field facilitates very much the learning of the students. For example, if the teacher considers that MOOCs facilitate much the organization of new school activities and has the specialty's degree then the use of ICT in the educational field facilitates very much the learning of the students. 
On the other hand, the PM3 has 3 predictive conditions related to the Much category about the learning of the students. For example, if the teacher considers that MOOCs facilitate much the organization of new school activities and has the master's degree then the use of ICT in the educational field facilitates much the learning of the students. Also, this predictive model has 2 predictive conditions related to the Little category about the learning of students. For example, if the teacher considers that MOOCs facilitate little the organization of new school activities then the use of ICT in the educational field facilitates little the learning of the students.

Finally, teachers use technology to improve the learning process inside and outside the classroom (Acher et al., 2017; Isomottonen \& Tirronen, 2017; Johnson, 2019). In particular, MOOCs facilitate the active participation of the students (Crues et al., 2018; Kurhila \& Vihavainen, 2015; Shukor \& Abdullah, 2019).

\section{CONCLUSION}

Technological advances are modifying the planning of the school activities. For example, teachers can use MOOCs to create new educational spaces and facilitate the learning process at any time. The results of machine learning indicate that the organization of the school activities in MOOCs positively influence the motivation, participation and learning of the students. This research recommends the incorporation of MOOCs and use of ICT in the educational field in order to facilitate the active role of the students.

According to the teachers of the National Autonomous University of Mexico, the organization of the school activities in MOOCs and use of ICT play a fundamental role during the COVID-19 pandemic. In fact, the decision tree technique indicates that the Maximum degree of study and Sex of the educators determine how the organization of the school activities in MOOCs influences the use of ICT for the motivation, participation and learning of the students.

The limitations of this research are the size of the sample, teachers' perception and analysis about the impact of technology in the motivation, participation and learning of the students. Therefore, future research can analyze the use of ICT and MOOCs considering the development of skills and satisfaction of the students during the learning process. Likewise, data collection can be carried out in high schools and universities to analyze the perception of the students about the incorporation of these technological tools.

The implications of this research promotes that teachers use MOOCs and ICT to improve the educational conditions, create new remote school activities and build new virtual learning spaces. In fact, the organization of the school activities in MOOCs allows the personalization of the learning process because students learn at their own pace and have access to content of the courses from anywhere. Likewise, students can actively participate before, during and after the classes through MOOCs and ICT.

In conclusion, universities with the support of technological tools can improve the teaching-learning process and update the course during the COVID-19 pandemic. In particular, MOOCs represent a technological alternative to transform the school activities in the 21st century.

Author contributions: All authors were involved in concept, design, collection of data, interpretation, writing, and critically revising the article. All authors approve final version of the article.

Funding: The authors received no financial support for the research and/or authorship of this article.

Declaration of interest: Authors declare no competing interest.

Data availability: Data generated or analysed during this study are available from the authors on request.

\section{REFERENCES}

Acher, M., López-Herrejón, R. E., \& Rabiser, R. (2017). Teaching software product lines: A snapshot of current practices and challenges. ACM Transactions on Computing Education, 18(1), 1-31. https://doi.org/10.1145/3088440

Adam, T. (2020). Open educational practices of MOOC designers: Embodiment and epistemic location. Distance Education, 41(2), 171-185. https://doi.org/10.1080/01587919.2020.1757405 
Albelbisi, N. A., Al-Adwan, A. S., \& Habibi, A. (2021). Impact of quality antecedents on satisfaction toward MOOC. Turkish Online Journal of Distance Education, 22(2), 164-175. https://doi.org/10.17718/tojde.906843

Albelbisi, N., \& Yusop, F. (2019). Factors influencing learners' self-regulated learning skills in a Massive Open Online Course (MOOC) environment. Turkish Online Journal of Distance Education, 20(3), 1-16. https://doi.org/10.17718/tojde.598191

Almatrafi, O., Johri, A., \& Rangwala, H. (2018). Needle in a haystack: Identifying learner posts that require urgent response in MOOC discussion forums. Computers \& Education, 118, 1-9. https://doi.org/10.1016/j.compedu.2017.11.002

Almeida, A. N., \& Hilleshein-de-Souza, M. L. (2020). Evaluation of the Pronatec courses: Benchmarking with long-term technical courses. Meta: Avaliação, 12(34), 88-117. https://doi.org/10.22347/21752753v12i34.2352

Arnavut, A., Bicen, H., \& Tugun, V. (2020). An evaluation of classroom teachers' opinions on online material preparation training through $\mathrm{MOOC}$ and blended education model. Turkish Online Journal of Distance Education, 21, 4-11. https://doi.org/10.17718/tojde.770887

Atencio, P., Sánchez-Torres, G., Iral-Palomino, R., Branch-Bedoya, J. W., \& Burgos, D. (2021). Conceptual architecture of the epidemiological surveillance technology platform for COVID-19. Campus Virtuales, 10(1), 21-34.

Bozkurt, A., Kilgore, W., \& Crosslin, M. (2018). Bot-teachers in hybrid massive open online courses (MOOCs): A post-humanist experience. Australasian Journal of Educational Technology, 34(3), 39-59. https://doi.org/10.14742/ajet.3278

Broeck, L. V., Laet, T. D., Lacante, M., Pinxten, M., Soom. C. V., \& Langie, G. (2020). The effectiveness of a $\mathrm{MOOC}$ in basic mathematics and time management training for transfer students in engineering. European Journal of Engineering Education, 45(4), 534-549. https://doi.org/10.1080/03043797.2019.1641692

Brooker, A., Corrin, L., De Barba, P., Lodge, J., \& Kennedy, G. (2018). A tale of two MOOCs: How student motivation and participation predict learning outcomes in different MOOCs. Australasian Journal of Educational Technology, 34(1), 73-87. https://doi.org/10.14742/ajet.3237

Carmo-Silva, M. D., Soares-de-Mello, J. S., Simoes-Gomes, C. F., \& Couto-Carlos, I. (2020). Efficiency analysis of scientific laboratories. Meta: Avaliação, 12(36), 625-645. https://doi.org/10.22347/2175$2753 v 12 i 36.2471$

Chen, C., Sonnert, G., Sadler, P. M., Sasselov, D. D., Fredericks, C., \& Malan, D. J. (2020). Going over the cliff: MOOC dropout behavior at chapter transition. Distance Education, 41(1), 6-25. https://doi.org/10.1080/01587919.2020.1724772

Chiu, T. K. F., \& Hew, T. K. F. (2018). Factors influencing peer learning and performance in MOOC asynchronous online discussion forums. Australasian Journal of Educational Technology, 34(4), 16-28. https://doi.org/10.14742/ajet.3240

Cisel, M. (2019). The structure of the MOOC ecosystem as revealed by course aggregators. American Journal of Distance Education, 33(3), 212-227. https://doi.org/10.1080/08923647.2019.1610285

Crues, R. W., Henricks, G. M., Perry, M. Bhat, S. P., Anderson, C. J., Shaik, N., \& Angrave, L. (2018). How do gender, learning goals, and forum participation predict persistence in a computer science MOOC? ACM Transactions on Computing Education, 18(4), 1-14. https://doi.org/10.1145/3152892

Del-Castillo-Olivares, J. M. \& Del-Castillo-Olivares, A. (2021). The impact of COVID-19 on higher education teachers and its conceptions on assessment. Campus Virtuales, 10(1), 89-101. 
Doo, M. Y., Tang, Y., Bonk, C. J., \& Zhu, M. (2020). MOOC instructor motivation and career development. Distance Education, 41(1), 26-47. https://doi.org/10.1080/01587919.2020.1724770

Fernandez-Díaz, E., Rodríguez-Hoyos, C., Belver-Dominguez, J., \& Calvo-Salvador, A. (2020). Who takes a MOOC? Profile of students in the framework of a European project. Turkish Online Journal of Distance Education, 21(2), 1-16. https://doi.org/10.17718/tojde.727968

Gamage, D., Perera, I., \& Fernando, S. (2020). Exploring MOOC user behaviors beyond platforms. International Journal of Emerging Technologies in Learning, 15(16), 161-179. https://doi.org/10.3991/ijet.v15i08.12493

Grande-de-Prado, M., García-Peñalvo, F. J., Corell Almuzara, A., \& Abella-García, V. (2021). Higher education assessment during COVID-19 pandemic. Campus Virtuales, 10(1), 49-58.

Gregori, E. B., Zhang, J., Galván-Fernández, C., \& Fernández-Navarro, F. A. (2018). Learner support in MOOCs: Identifying variables linked to completion. Computers \& Education, 122, 153-168. https://doi.org/10.1016/j.compedu.2018.03.014

Hsu, J. Y., Chen, C. C., \& Ting, P. F. (2018). Understanding MOOC continuance: An empirical examination of social support theory. Interactive Learning Environments, 26(8), 1100-1118. https://doi.org/10.1080/10494820.2018.1446990

Isomottonen, V., \& Tirronen, V. (2017). Flipping and blending - An action research project on improving a functional programming course. ACM Transactions on Computing Education, 17(1), 1-35. https://doi.org/10.1145/2934697

Jafari, E., Vajargah, K., Arefi, M., \& Rezaeizadeh, M. (2018). MOOC-based curriculum model validation in higher education in Iran. Turkish Online Journal of Distance Education, 19(3), 112-127. https://doi.org/10.17718/tojde.445112

$\mathrm{Ji}, \mathrm{Z}$. (2016). Application and empirical investigation of new MOOC teaching system in computer application course. International Journal of Emerging Technologies in Learning, 11(5), 62-67. https://doi.org/10.3991/ijet.v11i05.5696

Johnson, P. M. (2019). Design and evaluation of an "athletic" approach to software engineering education. ACM Transactions on Computing Education, 19(4), 1-25. https://doi.org/10.1145/3344273

Joo, Y. J., So, H. J., \& Kim, N. H. (2018). Examination of relationships among students' self-determination, technology acceptance, satisfaction, and continuance intention to use K-MOOCs. Computers \& Education, 122, 260-272. https://doi.org/10.1016/j.compedu.2018.01.003

Jung, Y., \& Lee, J. (2018). Learning engagement and persistence in Massive Open Online Courses (MOOCS). Computers \& Education, 122, 9-22. https://doi.org/10.1016/j.compedu.2018.02.013

Kang, I. G. (2020). Heterogeneity of learners' behavioral patterns of watching videos and completing assessments in Massive Open Online Courses (MOOCs): A latent class analysis. The International Review of Research in Open and Distributed Learning, 21(4), 222-237. https://doi.org/10.19173/irrodl.v21i4.4645

Kara, N. (2021). A systematic review of the use of serious games in science education. Contemporary Educational Technology, 13(2), ep295. https://doi.org/10.30935/cedtech/9608

Khalid, A., Lundqvist, K., \& Yates, A. (2020). Recommender systems for MOOCs: A systematic literature survey (January 1, 2012 - July 12, 2019). The International Review of Research in Open and Distributed Learning, 21(4), 255-291. https://doi.org/10.19173/irrodl.v21i4.4643 
Kim, S., Bindoff, A., Farrow, M., McInerney, F., Borchard, J., \& Doherty, K. (2021). Is the understanding dementia Massive Open Online Course accessible and effective for everyone? Native versus non-native English speakers. The International Review of Research in Open and Distributed Learning, 22(3), 19-33. https://doi.org/10.19173/irrodl.v22i3.5380

Kurhila, J., \& Vihavainen, A. (2015). A purposeful MOOC to alleviate insufficient CS education in Finnish schools. ACM Transactions on Computing Education, 15(2), 1-18. https://doi.org/10.1145/2716314

Lee, S., \& Chung, J. Y. (2019). Lessons learned from two years of K-MOOC experience. Educational Media International, 56(2), 134-148. https://doi.org/10.1080/09523987.2019.1614245

Li, H., Kim, M. K., \& Xiong, Y. (2020). Individual learning vs. interactive learning: A cognitive diagnostic analysis of MOOC students' learning behaviors. American Journal of Distance Education, 34(2), 121-136. https://doi.org/10.1080/08923647.2019.1697027

Li, J. (2017). Construction of modern educational technology MOOC platform based on courseware resource storage system. International Journal of Emerging Technologies in Learning, 15(16), 105-116. https://doi.org/10.3991/ijet.v12.i09.7491

Liu, L., Zhang, L., Ye, P., \& Liu, Q. (2018). Influence factors of satisfaction with mobile learning APP: An empirical analysis of China. International Journal of Emerging Technologies in Learning, 13(3), 87-99. https://doi.org/10.3991/ijet.v13i03.8381

Llorens-Largo, F., Villagrá-Arnedo, C., Gallego-Durán, F., \& Molina-Carmona, R. (2021). COVID-proof: how project-based learning has supported lockdown. Campus Virtuales, 10(1), 73-88.

Lorente-Ruiz, A., Despujol, I., \& Castañeda, L. (2021). MOOC as a leveling strategy in higher education: The case of the Polytechnic University of Valencia. Campus Virtuales, 10(2), 9-25.

Luik, P., \& Lepp, M. (2021). Are highly motivated learners more likely to complete a computer programming MOOC? International Review of Research in Open and Distributed Learning, 22(1), 41-58. https://doi.org/10.19173/irrodl.v22i1.4978

Mailizar, M., Almanthari, A., \& Maulina, S. (2021). Examining teachers' behavioral intention to use e-learning in teaching of mathematics: An extended TAM model. Contemporary Educational Technology, 13(2), ep298. https://doi.org/10.30935/cedtech/9709

Martin, N. I., Kelly, N., \& Terry, P. C. (2018). A framework for self-determination in massive open online courses: Design for autonomy, competence, and relatedness. Australasian Journal of Educational Technology, 34(2), 35-55. https://doi.org/10.14742/ajet.3722

Medina-Labrador, M., Gómez-Zermeno, M., \& Garza, L. D. (2020). Efficiency of biometric recognition technology based on typing dynamics in Mooc. Turkish Online Journal of Distance Education, 21, 7987. https://doi.org/10.17718/tojde. 770922

Njiku, J., Mutarutinya, V., \& Maniraho, J. F. (2021). Building mathematics teachers' TPACK through collaborative lesson design activities. Contemporary Educational Technology, 13(2), ep297. https://doi.org/10.30935/cedtech/9686

Oliveira, J. P. (2019). ICT and children's literature: challenges of pedagogical practice in the digital age. Texto Livre, 12(2), 116-134. https://doi.org/10.17851/1983-3652.12.2.116-134

Otto, D., Bollmann, A., Becker, S., \& Sander, K. (2018). It's the learning, stupid! Discussing the role of learning outcomes in MOOCs. Open Learning: The Journal of Open, Distance and e-Learning, 33(3), 203-220. https://doi.org/10.1080/02680513.2018.1486183 
Oudeweetering, K. V., \& Agirdag, O. (2018). Demographic data of MOOC learners: Can alternative survey deliveries improve current understandings? Computers \& Education, 122, 169-178. https://doi.org/10.1016/j.compedu.2018.03.017

Padilla-Rodriguez, B. C., Armellini, A., \& Rodriguez-Nieto, M. C. (2020). Learner engagement, retention and success: why size matters in massive open online courses (MOOCs). Open Learning: The Journal of Open, Distance and e-Learning, 35(1), 46-62. https://doi.org/10.1080/02680513.2019.1665503

Papadakis, S., Kalogiannakis, M., Sifaki, E., \& Vidakis, N. (2017). Access Moodle using smart mobile phones. A case study in a Greek University. In A. Brooks, E. Brooks, \& N. Vidakis (Eds.), Interactivity, game creation, design, learning, and innovation (pp. 376-385). Springer. https://doi.org/10.1007/978-3-31976908-0_36

Papadakis, S., Kalogiannakis, M., Sifaki, E., \& Vidakis, N. (2018). Evaluating Moodle use via smart mobile phones. A case study in a Greek University. EAl, 5(16), e1. https://doi.org/10.4108/eai.10-42018.156382

Paton, R. M., Fluck, A. E., \& Scanlan, J. D. (2018). Engagement and retention in VET MOOCs and online courses: A systematic review of literature from 2013 to 2017. Computers \& Education, 125, 191-201. https://doi.org/10.1016/j.compedu.2018.06.013

Persson, V., \& Nouri, J. (2018). A systematic review of second language learning with mobile technologies. International Journal of Emerging Technologies in Learning, 13(2), 188-210. https://doi.org/10.3991/ijet.v13i02.8094

Pilli, O., \& Admiraal, W. (2016). A taxonomy of massive open online courses. Contemporary Educational Technology, 7(3), 223-240. https://doi.org/10.30935/cedtech/6174

Poultsakis, S., Papadakis, S., Kalogiannakis, M., \& Psycharis, S. (2021). The management of digital learning objects of natural sciences and digital experiment simulation tools by teachers. Advances in Mobile Learning Educational Research, 1(2), 58-71. https://doi.org/10.25082/AMLER.2021.02.002

Salas-Rueda, R. A., Eslava-Cervantes, A. L., \& Prieto-Larios, E. (2020). Teachers' perceptions about the impact of Moodle in the educational field considering data science. Online Journal of Communication and Media Technologies, 10(4), e202023. https://doi.org/10.30935/ojcmt/8498

Santoso, H. D., Desprianto, D. A., Nurrohmah, I., Nursalamah, R. K., \& Putra, H. D. (2019). Customer journey construction of the Indonesian OpenEducation resources platform. International Journal of Emerging Technologies in Learning, 14(24), 18-30. https://doi.org/10.3991/ijet.v14i24.12045

Shen, C. (2018). MOOC teaching mode of news transmission based on network audio data decoding technology. International Journal of Emerging Technologies in Learning, 15(16), 43-55. https://doi.org/10.3991/ijet.v13i06.8582

Shukor, N. A., \& Abdullah, Z. (2019). Using learning analytics to improve MOOC instructional design. International Journal of Emerging Technologies in Learning, 15(16), 6-17. https://doi.org/10.3991/ijet.v14i24.12185

Thomas, D. A., \& Nedeva, M. (2018). Broad online learning EdTech and USA universities: symbiotic relationships in a post-MOOC world. Studies in Higher Education, 43(10), 1730-1749. https://doi.org/10.1080/03075079.2018.1520415

Tsai, Y. H., Lin, C. H., Hong, J. C., \& Tai, K. H. (2018). The effects of metacognition on online learning interest and continuance to learn with MOOCs. Computers \& Education, 121, 18-29. https://doi.org/10.1016/j.compedu.2018.02.011

Vaz-de-Oliveira, U. T. (2017). Language learning in blended and tandem with Brazilian partners: Flexible learning models. Texto Livre, 10(2), 123-144. https://doi.org/10.17851/1983-3652.10.2.123-144 
Wahid, R., Ahmi, A., \& Alam, A. F. (2020). Growth and collaboration in massive open online courses: A bibliometric analysis. The International Review of Research in Open and Distributed Learning, 21(4), 292-322. https://doi.org/10.19173/irrodl.v21i4.4693

Watson, W. R., Yu, J. H., \& Watson, S. L. (2018). Perceived attitudinal learning in a self-paced versus fixedschedule MOOC. Educational Media International, 55(2), 170-181. https://doi.org/10.1080/09523987.2018.1484044

Wise, A. F., \& Cui, Y. (2018). Learning communities in the crowd: Characteristics of content related interactions and social relationships in MOOC discussion forums. Computers \& Education, 122, 221242. https://doi.org/10.1016/j.compedu.2018.03.021

Xing, W. (2019). Exploring the influences of MOOC design features on student performance and persistence. Distance Education, 40(1), 98-113. https://doi.org/10.1080/01587919.2018.1553560

You, H. W. (2019). Students' perception about learning using MOOC. International Journal of Emerging Technologies in Learning, 14(18), 203-208. https://doi.org/10.3991/ijet.v14i18.10802

Zhang, M., Yin, S., Luo, M., \& Yan, W. (2017). Learner control, user characteristics, platform difference, and their role in adoption intention for MOOC learning in China. Australasian Journal of Educational Technology, 33(1), 114-133. https://doi.org/10.14742/ajet.2722

Zhang, Y. \& Zuo, L. (2019). College English teaching status and individualized teaching design in the context of mobile learning. International Journal of Emerging Technologies in Learning, 14(12), 85-96. https://doi.org/10.3991/ijet.v14i12.10704

Zhang, Y., Chen, J., Miao, D., \& Zhang, C. (2018). Design and Analysis of an Interactive MOOC Teaching System Based on Virtual Reality. International Journal of Emerging Technologies in Learning, 13(7), 111-123. https://doi.org/10.3991/ijet.v13i07.8790

Zhou, J. (2017). Exploring the factors affecting learners' continuance intention of MOOCs for online collaborative learning: An extended ECM perspective. Australasian Journal of Educational Technology, 33(5), 123-135. https://doi.org/10.14742/ajet.2914

Zhu, M., Sabir, N., Bonk, C. J., Sari, A., Xu, S., \& Kim, M. (2021). Addressing learner cultural diversity in MOOC design and delivery: Strategies and practices of experts. Turkish Online Journal of Distance Education, 22(2), 1-25. https://doi.org/10.17718/tojde.906468

Correspondence: Ricardo-Adán Salas-Rueda, Institute of Applied Sciences and Technology, National Autonomous University of Mexico, Mexico. E-mail: ricardo.salas@icat.unam.mx 